\title{
Revisiting the Carmen Christi: Paul's Perspective on Humiliation and Exaltation in Philippians 3:7-11
}

Rachael Tan

Taiwan Baptist Christian Seminary, Taiwan

\begin{abstract}
Philippians 2:5-11 is one of the key passages in Paul's letter to the Philippians. A proper interpretation of this important carmen Christi (hymn of Christ) will unpack the kind of attitude that Jesus adopts. It is common to pit the two main streams of interpretation (kerygmatic and ethical) against each other. I argue that this is a false dichotomy since a doctrinal exposition does not cancel out its ethical implications, and Pauline ethics is often grounded in theological foundations. Paul integrates both theology and ethics in the letter. The only possible way for believers to live in harmony with each other in the Lord is to have the mind of Christ in dogma and praxis. Jesus Christ is the ultimate pattern to which we are being conformed in the way we think, feel, decide, and act (cf. Phil 3:10).

Keywords: Carmen Christi, Hymn of Christ, humiliation, exaltation, phroneō, conformatio Christi, conformity to Christ, Christocentric ethics, kerygmatic interpretation, ethical interpretation, imitatio Christi, Philippians
\end{abstract}

Philippians 2:5-11 is one of the most important yet one of the most difficult passages in Philippians to interpret. It is also "one of the most exalted, most beloved, and most discussed and debated passages in the Pauline corpus" (Fee, 1995, p. 192). Most of the research centers around the literary form, background, source, and authorship of the hymn. Although these issues are 
significant and have been adequately investigated but lacking any consensus, I will not dwell on them in this paper.

In revisiting the Carmen Christi (Christ-hymn), I will focus on two aspects to

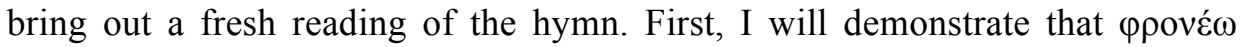
(phroneō) in Philippians 2:5 is a significant word carefully chosen by Paul to highlight the importance of cultivating a Christ-centered thinking in his urgent call for unity in his letter to the Philippians. It is often neglected yet it is the missing link in understanding Paul's perspective on humiliation and exaltation and in the interpretation of the carmen Christi. Second, Paul's narrative in Philippians 3:7-11 serves as a good parallel passage for comparison with Christ's story in Philippians 2:5-11. It offers a closer look at Paul's perspective on humiliation and exaltation. This essay is divided into five sections: (1) Theme of unity in Philippians; (2) Significance of phroneō; (3) Paul's perspective on humiliation and exaltation; (4) Interpretation of the carmen Christi; and (5) conclusion.

\section{Theme of Unity in Philippians}

Philippians is one of the seven universally accepted epistles of Paul and even "deserves to be ranked with the Hauptbriefe" (Hawthorne, 1983). This distinctly personal letter of the apostle to the first church he founded in Europe in response to the Macedonian call (Acts 16) reveals a close bond between him and the believers. He openly expresses his longing for them (Phil 1:7-8) and commends them for their "partnership in the gospel from the first day until now" (Phil 1:5 NIV). He writes this letter to thank them for the gift they sent through Epaphroditus and he appreciates their support throughout his ministry (Phil 4:10-20). The warm relationship and repeated stress on rejoicing have led many readers to picture the Philippian church as a perfect community devoid of any problems. However, various passages in the letter provide hints that the church is experiencing internal strife arising from envy, conceit, selfish ambition (Phil 2:1-4). Paul urges them to be united, which is only possible if they conform to Christ in his humility and selflessness (2:5-11). He also pleads with Euodia and Syntyche to live in harmony with one another (4:2). In his exhortations to unity, Paul carefully employs the word $\varphi \rho o v \varepsilon ́ \omega$ to highlight the importance of cultivating a Christ-centered thinking, feeling, and attitude that will foster the spirit of unity. 


\section{Significance of $\varphi \rho \operatorname{vv}_{\varepsilon} \omega$}

Paul's use of $\varphi \rho o v \varepsilon ́ \omega$ in Philippians is remarkable in both frequency and significance. In terms of frequency it occurs ten times in the epistle out of the twenty-six occurrences in the NT. In terms of significance it appears in key passages which suggests that Paul has carefully and deliberately chosen the word to unpack the main thrust of this letter (Fee, 1995; Fowl, 2005; O'Brien, 1991). The verb is an important and distinct Pauline term related to the central theme of Philippians (Hawthorne, 1983; O'Brien, 1991; Fowl, 2005).

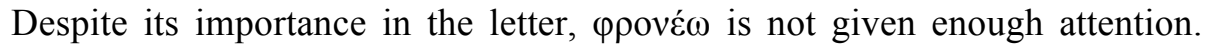
Silva observes that "this peculiarity has often been mentioned by commentators but seldom developed" and a thorough treatment only appears in the important monograph of Jozef Heriban (Silva, 2005, p. 21; see Heriban, 1983). Heriban in his review of O'Brien's commentary laments that the latter has not allotted more space and attention to this important term (Heriban, 1994). Most of the commentators will mention their observation of the high frequency of $\varphi \rho o v \varepsilon \dot{\varepsilon} \omega$ in their introduction and briefly comment that this term is important to the letter, but fail to elucidate why it is important and how it affects our understanding of Paul's message in the letter. Some commentators will simply introduce the various meanings of the word only once in the commentary (either in 1:7 when it occurs for the first time, or when it occurs in a Christologically significant passage like 2:1-11) and fail to mention it thereafter. The significance of

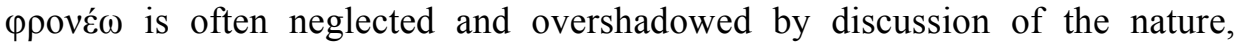
source, and interpretation of Philippians 2:5-11, eclipsed by well-loved verses and favorite themes of joy, unity, and humility, and surpassed by debates on the provenance and literary integrity of the letter and the identity of Paul's opponents in Philippians 3.

If $\varphi \rho o v \varepsilon ́ \omega$ is not given due attention in the Greek text, then it is even more difficult for English readers to see its importance in the letter. The translation of the term into English presents many challenges. The biggest problem related to translation is that $\varphi \rho o v \varepsilon \dot{\varepsilon} \omega$ has a vast semantic range which cannot be fully captured by any single English word. It is so easy for English readers to miss it because it necessitates more than one rendering in different contexts (Silva, 2005). It is a difficult word to translate because it not only consists of attitude and feeling, but also thoughts and opinion about someone or something

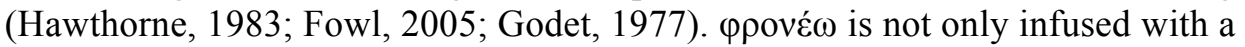

William Loader, Boris Repschinski, Eric Wong (Eds.)

Matthew, Paul, and Others: Asian Perspectives on New Testament Themes

(C) 2019 innsbruck university press, ISBN 978-3-903187-66-5, DOI 10.15203/3187-66-5 
wide range of meaning, but its collocation with other words affects its meaning. For instance, $\varphi \rho o v \varepsilon \dot{\varepsilon} \omega$ vं $\pi \dot{\varepsilon} \rho$ or $\dot{\varepsilon} \pi \dot{i}$ in Philippians $1: 7 ; 4: 10$ connotes thoughtful thinking and action (The theological dictionary of the New Testament [TDNT], 1974). A survey of the major English translations of the ten occurrences in Philippians will reveal that none of them rendered the verb consistently by its primary meaning (i.e., to think) throughout the letter.

The verb $\varphi \rho o v \varepsilon ́ \omega$ belongs to the word group that is derived from the feminine noun $\varphi \rho \eta v$. The noun refers to the diaphragm in the anatomical sense (usually in plural form $\varphi \rho \varepsilon \dot{v \varepsilon} \varsigma$ ), and refers figuratively to the heart or soul as the seat of emotions and passions, the mind as seat of mental faculties and forethought, and will or purpose (The Brill dictionary of ancient Greek, 2015; TDNT, 1974; Etymological dictionary of Greek [EDNT], 2010; A Greek-English lexicon [LSJM], 1996; Greek-English lexicon of the New Testament based on semantic

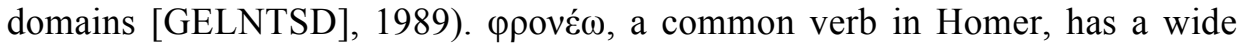
semantic range and retains most of the root meanings of $\varphi \rho \eta \dot{~} v$, but the physical sense is lost over time (TDNT, 1974). The primary meaning of $\varphi \rho o v \varepsilon ́ \omega$ is to think or reflect. This basic meaning comprises at least six overlapping ideas: (1) "think, form/hold an opinion, judge" (1 Cor 13:11; Acts 28:22; Rom 12:3a); (2) "think or feel in a certain way about someone" (Phil 1:7); (3) "think of someone in the sense be concerned about him" (Phil 4:10a); (4) "think the same thing, i.e., be in agreement, live in harmony" (Phil 2:2a; 4:2; 2 Cor 13:11; Rom 12:16; 15:5); (5) "think nothing different" or "not take a different view" (Gal 5:10) or "think of or regard something differently" (Phil 3:15); and (6) "be proud" (Rom

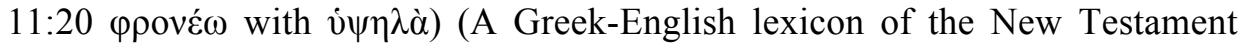
and other early Christian literature [BDAG], 2000, p. 1065). It carries with it an element of commitment with intentionality (The Brill dictionary of ancient Greek, 2015). The verb also refers to cultivating an attitude that involves careful thinking and planning (Reed, 1997; BDAG, 2000; GELNTSD, 1989). $\varphi \rho o v \varepsilon ́ \omega$ involves not only the mind, but also the will and emotions, and also affects one's attitude (New international dictionary of New Testament theology and exegesis [NIDNTTE], 2014). Ernst Käsemann (1980) is on-target when he says that it "denotes the direction not merely of thought but of total existence, which on the Semitic view is always oriented consciously or unconsciously to a goal" (p. 219).

Other cognates are the nouns $\varphi \rho o ́ v \eta \sigma ા \varsigma$ and $\varphi \rho o ́ v \eta \mu \alpha$, adjective $\varphi \rho o ́ v \imath \mu о \varsigma$, and adverb $\varphi \rho o ́ v ı \mu \omega \varsigma$. The nouns $\varphi \rho o ́ v \eta \sigma ı \varsigma$ and $\varphi \rho o ́ v \eta \mu \alpha$ are both post-Homeric

William Loader, Boris Repschinski, Eric Wong (Eds.)

Matthew, Paul, and Others: Asian Perspectives on New Testament Themes

(C) 2019 innsbruck university press, ISBN 978-3-903187-66-5, DOI 10.15203/3187-66-5 
with the former pertaining to insight, understanding, reason, cleverness, and practical intelligence and the latter to one's frame of mind, disposition, and temperament (which could be either positive or negative), but the difference between the two nouns is not significant (NIDNTTE, 2014). The adjective $\varphi \rho o ́ v ı \mu$ s describes someone who is wise, sensible, prudent, and insightful while the adverb $\varphi \rho \operatorname{vov}_{\mu} \omega \varsigma$ describes an action done wisely, prudently, or shrewdly (EDNT, 1993).

\section{Synonyms of $\varphi \rho o v \varepsilon ́ \omega$}

Paul has several Greek words to choose from and he could have used any the following verbs that also mean "think." The verb voś $\omega$, which means to think or consider something carefully, may be considered a close synonym of $\varphi \rho o v \varepsilon ́ \omega$. But unlike $\varphi \rho o v \varepsilon \dot{\varepsilon} \omega$, it does not have the dynamic sense that involves the will, emotions, and attitude (GELNTSD, 1989). Another synonym is $\lambda$ o $\gamma^{\prime} \zeta \zeta_{0} \mu \alpha$ which means to think of something more logically and systematically (GELNTSD, 1989). Another possible option is the verb $\gamma^{\prime} \varepsilon \varepsilon^{\circ} \alpha \iota$ which usually involves a mental process of regarding or considering something (BDAG, 2000). Two more verbs that emphasize the intellectual process of thinking

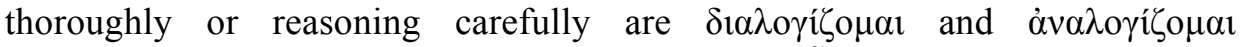

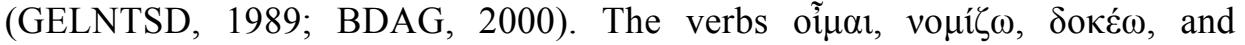

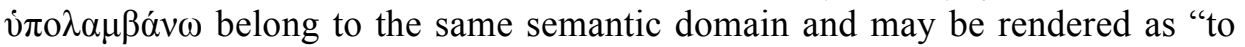
think," but with a degree of uncertainty (GELNTSD, 1989).

Paul could have chosen any of these synonymous terms, but there are two aspects of the lexical meaning of $\varphi \rho o v \varepsilon \dot{\omega} \omega$ that are lacking in them. Only $\varphi \rho o v \varepsilon \dot{\varepsilon} \omega$ encompasses the mind, will, emotions, and attitude and thus it is more comprehensive in its scope. Only $\varphi \rho o v \varepsilon ́ \omega$ expresses focus, intention, and commitment. We may then say that Paul has chosen this word carefully to articulate the seriousness of the issue of unity and the intensity of effort that the believers should invest in order to ensure that harmony is achieved.

\section{$4 \varphi \rho o v \varepsilon ́ \omega$ in the NT}

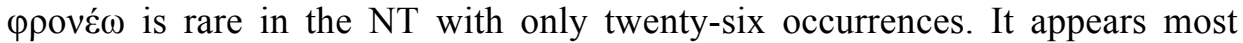
frequently in Pauline passages and only three times in other NT passages. Even

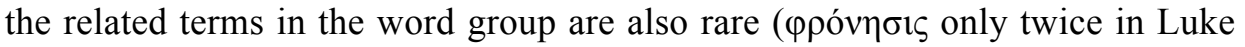

William Loader, Boris Repschinski, Eric Wong (Eds.)

Matthew, Paul, and Others: Asian Perspectives on New Testament Themes

(C) 2019 innsbruck university press, ISBN 978-3-903187-66-5, DOI 10.15203/3187-66-5 
1:17 and Eph 1:8; $\varphi \rho o ́ v \eta \mu \alpha$ only four times which all occurs in Rom 8;

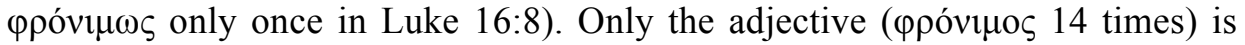
more frequent.

The verb appears ten times in seven verses in the short letter of Philippians (1:7; 2:2 [twice], 5; 3:15 [twice], 19; 4:2, 10 [twice]). The other sixteen occurrences appear thirteen times in other Pauline letters (Rom 8:5; 11:20; 12:3 [twice], 16 [twice]; 14:6 [twice]; 15:5; 1 Cor 13:11; 2 Cor 13:11; Gal 5:10; Col $3: 2$ ) and only three in non-Pauline literature (Matt 16:23; Mark 8:33; Acts 28:22). Interestingly, $\varphi \rho o ́ v \eta \mu \alpha$ always occurs in tandem with $\varphi \rho \circ v \varepsilon ́ \omega$ in four occurrences (Rom 8:6 [twice], 7, 27) in the NT (TDNT, 1974). The $\varphi \rho o v \varepsilon ́ \omega$ in Romans 8:5 carries the sense of focus and intent. Those who are according to the flesh focus on the things of the flesh, whereas those who are according to the Spirit, focus on the things of the Spirit (cf. "set their minds" in NIV, NRSV, NASB, and ESV). The verb is coupled with the adjective vim $\lambda$ ó $\varsigma$ and negated by $\mu$ in in Rom 11:20, whereby the apostle is admonishing the Roman believers not to be conceited or arrogant (literally "to think high") in light of Israel's judgment because of unbelief. In Rom 12:3 the infinitive form $\varphi \rho o v \varepsilon i v$ is used twice and juxtaposed with the compounded infinitives $\dot{v} \varepsilon \varepsilon \rho \varphi \rho \varepsilon_{\varepsilon} \tilde{v} v$ and

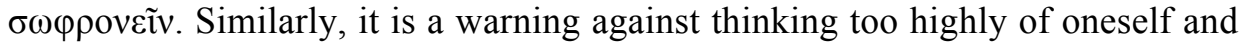
a call to regard oneself with sober judgment. The participial form of the verb is used twice in Romans 12:16, but yielding a slightly different meaning due to their collocation. In the first part of the verse $\tau$ ò $\alpha$ v่ emphasis to unity or literally "to think the same thing" (cf. "be of the same mind" in NASB; "live in harmony" in NRSV, NIV, and ESV). The second part

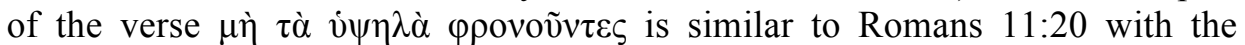
article and the plural form of the adjective and negated by $\mu$, which also warns

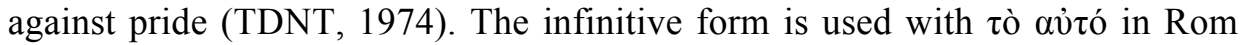
15:5 and 2 Corinthians 13:11 to exhort the believers toward concord and harmony as in Rom 12:16a (TDNT, 1974). In 1 Corinthians 13:11 the imperfect

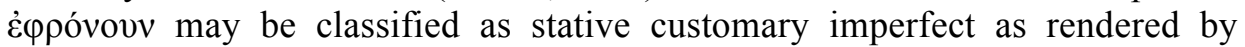
NASB: "I used to . . . think," and connotes the basic meaning of "think" (Wallace, 548). Paul uses the future tense of the verb in Galatians 5:10 to speak of his certainty that the Galatian Christians will not adopt other views contrary to the gospel message that the apostle has proclaimed to them (TDNT, 1974). The apostle commands the Colossian believers to set their minds (imperative

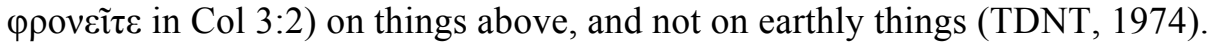

William Loader, Boris Repschinski, Eric Wong (Eds.)

Matthew, Paul, and Others: Asian Perspectives on New Testament Themes

(C) 2019 innsbruck university press, ISBN 978-3-903187-66-5, DOI 10.15203/3187-66-5 


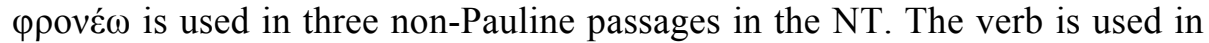
the usual sense in Acts 28:22 when the Jewish leaders in Rome asked Paul for his view or opinion (EDNT, 1993; TDNT, 1974). In Matthew 16:23 and Mark 8:33 Jesus severely rebuked Peter for setting his mind on human concerns, rather than the things of God.

\section{Synthesis}

It is evident from the foregoing discussion that a wide array of meanings is attached to $\varphi \rho o v \varepsilon ́ \omega$. These meanings are vastly different from the concept of thinking in English, which is simply an intellectual activity or mental process. The Greek verb refers "neither to 'thinking' in general, nor 'reasoning' as such, nor is it used for a specific act or thought," Fee clarifies, "rather, it has to do with having or developing a certain 'mindset' including attitudes and dispositions" (Fee, 1995, p. 89). It usually occurs within a theological context such as when Jesus confronts Peter that his mindset is not godly but human (NIDNTTE, 2014, p. 619). There is no middle ground, one sets one's mind either on God or on the things against God. The harsh rebuke to Peter that was aimed at Satan highlights this point sharply (EDNT, 1993). Thinking does not occur in a vacuum and Silva is right in saying that it can never be neutral (NIDNTTE, 2014). In Romans 8:5, it is clear that thinking can either be swayed by the desires of the flesh or it can be guided by the Spirit (NIDNTTE, 2014). In Colossians 3:2 Paul exhorts believers to set their mind on things above, rather than on earthly things (also Phil 3:19). These contrasts-godly and human, fleshly and spiritual, heavenly and earthly - reveal that the meaning of the word can be expanded to connote making choices and even of taking sides (BDAG, 2000; NIDNTTE, 2014). Thus it is proper to say that we should be intentional in directing the course of our thoughts and allow the Spirit to shape how we view and evaluate things. Cultivating a right mindset is foundational to living a life that honors God and edifies the church.

Hence, it is a challenge to translate $\varphi \rho o v \varepsilon ́ \omega$ in a more holistic way as Paul intended his readers to understand it - not the slavish kind of thinking that focuses only on the intellectual, dogmatic, rational, or theoretical, but he wants them to adopt the right attitude of mind with renewed thinking and genuine concern as seen in Christ (2:5-11). Paul knows that the Philippian problem of disunity cannot be resolved by dictating to the believers a certain kind of

William Loader, Boris Repschinski, Eric Wong (Eds.)

Matthew, Paul, and Others: Asian Perspectives on New Testament Themes

(C) 2019 innsbruck university press, ISBN 978-3-903187-66-5, DOI 10.15203/3187-66-5 
behavior. Rather he is persuading them to have the right $\varphi \rho o v \varepsilon \dot{\varepsilon} \omega$ that will directly affect how they act and behave towards each other and resolve their problem. He also warns them that the wrong kind of $\varphi \rho o v \varepsilon \dot{\varepsilon} \omega$ that is focused on earthly things will make them enemies of the cross (3:18-19).

\section{Paul's Perspective on Humiliation and Exaltation}

Paul's narrative in Philippians 3:7-11 serves as a good parallel passage for comparison with Christ's story in Philippians 2:5-11. It offers a closer look at Paul's perspective on humiliation and exaltation. The former exhibits a high degree of correspondence with the latter through verbal links and thematic association. First, verbal connection is evident in the use of four terms in both

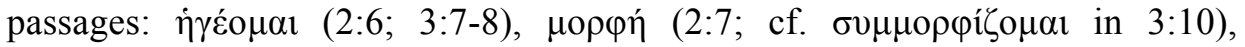

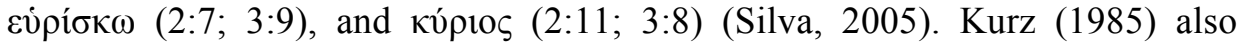
identifies $\eta \gamma \varepsilon$ o $\mu \alpha \mathrm{l}$ in 3:7-8 as a significant link to 2:6. Fee (1995) considers the link between "being conformed" and "death" in Philippians 3:10 as "the strongest kind of linguistic ties" between the narratives of Christ and Paul (p. 333).

Second, thematic correspondence is evidenced by Paul's decision to renounce all his Jewish privileges to know Christ and be conformed to the pattern of his death which serves as an analogy to the self-emptying act of Christ (Pollard, 1966; Byrnes, 2003; Silva, 2005; Hansen, 2009; Brown, 1998, p. 29; DeSilva, 1994; Garland, 1985). Christ did not consider (aorist $\eta \gamma \eta \sigma \alpha \tau o ~ 2: 6$ ) his equality with God as something to be taken advantage of, so Paul has considered (perfect

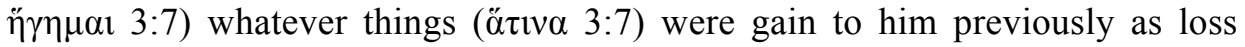
hereafter because of Christ. Jesus emptied himself, so Paul also considers (present $\dot{\eta} \gamma o \tilde{v} \mu \alpha \iota$ 3:8) everything ( $\pi \dot{\alpha} \nu \tau \alpha)$ as loss because of the surpassing value of knowing Christ Jesus. Being found in appearance as a human being (aorist

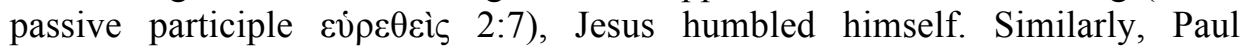
relinquishes everything precious to him so that he will be found in him (aorist passive subjunctive ev $\rho \varepsilon \theta \tilde{\omega}$ 3:9) (Hansen, 2009). Like Jesus who takes the form

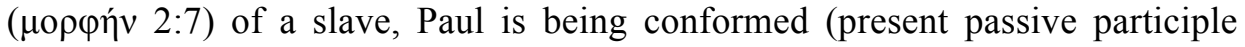
$\sigma v \mu \mu о \rho \varphi 1 \zeta o$ $\mu \varepsilon v o \varsigma$ 3:10) to his death by experiencing the power of his resurrection and sharing in his sufferings. He also acknowledges Christ Jesus, the one whom every tongue should confess that "Jesus Christ is Lord" (кúpios

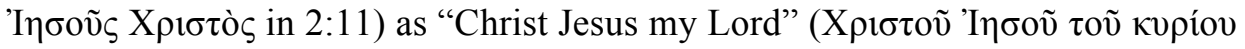

William Loader, Boris Repschinski, Eric Wong (Eds.)

Matthew, Paul, and Others: Asian Perspectives on New Testament Themes

(C) 2019 innsbruck university press, ISBN 978-3-903187-66-5, DOI 10.15203/3187-66-5 
Hov 3:8). Like Christ whom God has exalted, Paul looks forward to being raised from the dead (Pollard, 1966). One other important thematic connection that is rarely noticed is Paul asserts he wants to know Christ (infinitive $\gamma v \tilde{\omega} v \alpha \mathrm{l}$ in 3:10) and extols the surpassing value of knowing Christ (genitive noun $\gamma v \omega \dot{\sigma \varepsilon} \omega \varsigma$ in $3: 8)$. Both knowledge terms are intricately related to the mind of Christ in the Christ-hymn. Koperski (1996) makes this well-suited connection:

An important function of the knowledge of Christ terminology is the subjective perception which is able to recognize that the crucified Christ is now the exalted Lord of glory, and further, on the basis of that act of discernment, to trust that this Christ is savior of those who acknowledge him as Lord. This ability to perceive correctly despite outward appearances, which has come to Paul with the knowledge of Christ, is something which Christ had already (cf. 2:6), when, being in the form of God, he did not hesitate to voluntarily empty himself and take the form of a slave (pp. 290-291).

There are some scholars who suggest that Paul is echoing Philippians 2:5-11 when he penned the profoundly personal yet highly Christological words in Philippians 3:7-11. Unfortunately, most of them do not go beyond alluding to these links and examine the relationship further. In the introductory chapter of his Philippians commentary, Silva (2005) observes that the astonishing frequency of $\varphi \rho o v \varepsilon ́ \omega$ in the letter points to its significance and also hints that it

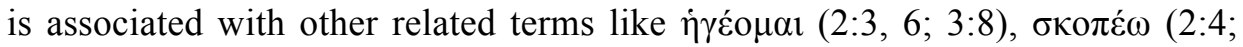

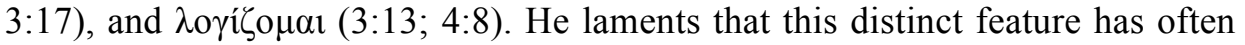
been hinted at by commentators but has not been developed except for the monograph of Josef Heriban (1983). Nevertheless, Silva himself fails to

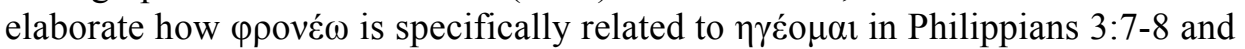
its impact on how Paul reckons his gains and losses.

Despite the overflow of secondary literature and intense scrutiny of each of these two passages, there is very little in-depth study of their relationship. Kurz (1985) explains that this apparent neglect is because of critical methods which treats these two chapters as fragments from different letters and Philippians 2:611 is often treated as an isolated hymn. Hence, many fail to notice the parallelism. Kurz (1985) advocates a strong parallelism between the second and third chapters of Philippians. Most scholars usually do not mention or discuss these two passages together.

Although Paul did not use $\varphi \rho o v \varepsilon ́ \omega$ in Philippians 3:7-11, he employs the verb $\dot{\gamma} \gamma \varepsilon \dot{\varepsilon} \mu \alpha \mathrm{l}$ which corresponds to the verb in Philippians 2:6, and also belongs to

William Loader, Boris Repschinski, Eric Wong (Eds.)

Matthew, Paul, and Others: Asian Perspectives on New Testament Themes

(C) 2019 innsbruck university press, ISBN 978-3-903187-66-5, DOI 10.15203/3187-66-5 
the same semantic domain as $\varphi \rho o v \varepsilon \dot{\varepsilon} \omega$ (GELNTSD, 1989). The word $\eta \gamma \varepsilon \dot{o} \mu \alpha 1$ means "think, consider, regard" (BDAG, 2000, p.434). It was not a subjective decision based on erratic moods or impulsive choice; rather it is an objective and cautious assessment after carefully weighing all available options. We should not think that the things he mentioned in Philippians 3:5-6 are unattractive and unimportant to him so that it would have been easy for him to count them as loss. On the contrary, they are things he held dear and worked hard for. He exclaims, "I was advancing in Judaism beyond many Jews of my own age and was extremely zealous for the traditions of my fathers" (Gal 1:14 NIV). Paul also does not demean his Jewish heritage, nor are they considered evil in themselves. The primary focus here is Paul's perspective towards these things ("I have come to consider"), and not a negative evaluation of his race, culture, and legacy (Fee, 1999). By using the perfect tense (ฑ $\gamma \eta \mu \alpha l)$ in tandem with ö $\tau \imath v \alpha$ (3:7), he is expressing an action in the past with ongoing effects in

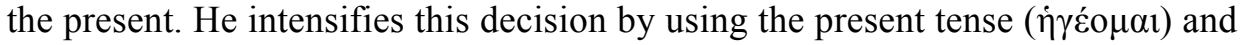
escalating it to encompass everything ( $\pi \alpha \dot{v} \tau \alpha \alpha$ in $3: 8$ ).

After declaring the surpassing value of knowing Christ in verse 8, Paul clearly states his desire is to know Christ by using the genitive articular

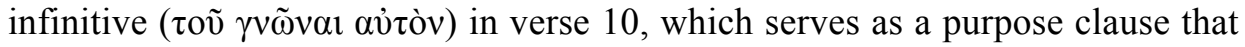
parallels the twofold iv $\alpha$ clause in verses 8-9 (Silva, 2005; O’Brien, 1991). He articulates his Christocentric goals in three different expressions that reveal his single-minded focus and unadulterated passion for Christ: to gain Christ, be found in him, and know him. Tannehill (1967) comments, "Each of these phrases expresses the purpose for which Paul renounced all things, and basically they contain the same idea" (p. 118). Hansen (2009) points out that "by restating his goals in these different ways, Paul keeps the focus completely on Christ and emphasizes that his relationship with Christ totally eclipses everything else in his life" (p. 242).

The aorist active infinitive $\gamma v \tilde{\omega} v \alpha$ comes from the verb $\gamma 1 v \omega$ $\sigma \kappa \omega$ which means to know or be acquainted with (GELNTSD, 1989). Paul's use of the active voice reveals the intensity with which he actively seeks to know Christ. He explains that he wants to know him, not just about him. Witherington (2011) defines this kind of knowing as "understanding through experiencing" (p. 205). He wants to know the person depicted in Philippians 2:5-11, his divinity and humanity (preexistence, incarnation, exaltation), his excellent qualities (humility, obedience, and self-sacrifice), his mindset (how he thinks, feels,

William Loader, Boris Repschinski, Eric Wong (Eds.)

Matthew, Paul, and Others: Asian Perspectives on New Testament Themes

(C) 2019 innsbruck university press, ISBN 978-3-903187-66-5, DOI 10.15203/3187-66-5 
chooses, decides, evaluates), his humiliation and exaltation. Paul further elaborates with an epexegetical kai that he also wants to know the power of his resurrection and fellowship of his sufferings.

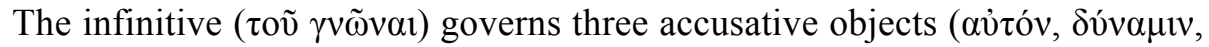

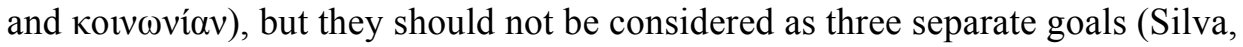

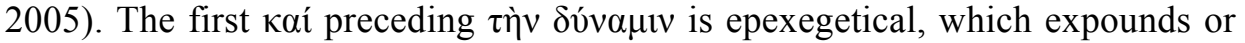
provides content to what it means to know Christ: "so that I may know him, that is, the power of his resurrection and participation in his sufferings" (Fee, 1995, p. 328, emphasis original; Silva, 2005, Tannehill, 1967). Hawthorne and Martin

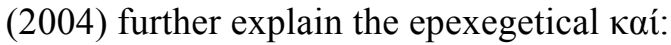

'It serves to link the words that follow together with av่ óv, 'him,' in such a way as to define and more fully explain what is meant by av่ not that Paul is saying 'I want to know him and the power of his resurrection,' as though 'him' and 'power' were equally worthy objects of his knowing. Rather, he is saying 'I want to know him in the power of his resurrection' . . .

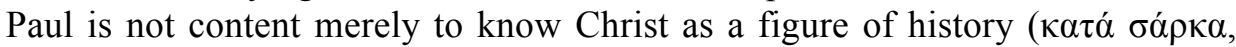
'according to the flesh') but he desires to know him personally as the

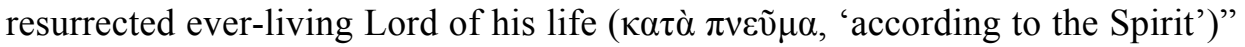
(p. 197, emphasis original).

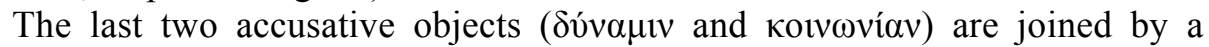
common article ( $\tau \dot{\eta} v)$ which shows that both the power of his resurrection and the fellowship of his sufferings are interwoven as complementary aspects of knowing Christ (Tannehill, 1967; Hansen, 2009). It is worth noting that in the noun phrases that come after the epexegetical $\kappa \alpha$ í, the accusative nouns $\delta v i v \alpha \mu v$

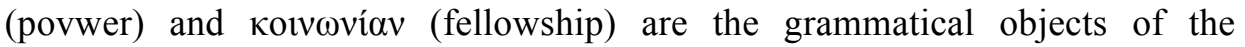

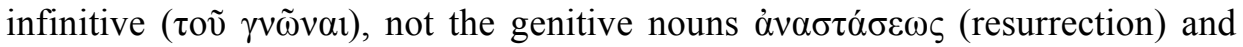
$\pi \alpha \theta \eta \mu \alpha \dot{\tau} \omega \nu$ (sufferings) as most interpreters have wrongly emphasized (O’Brien, 1991).

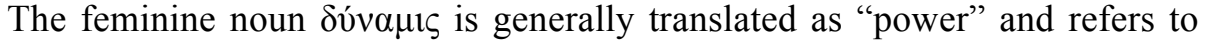
the ability or capability to perform a certain activity or to go through some experiences (GELNTSD, 1989; BDAG, 2000). The genitive $\alpha v \alpha \sigma \tau \alpha ́ \sigma \varepsilon \omega \varsigma$ (resurrection) qualifies the specific power Paul is referring to. It may be interpreted as a genitive of source, i.e., the power springing forth from his resurrection, which does not refer to the power that raised Christ from the dead or the power that will raise believers in the last day (O'Brien, 1991). It refers instead to the power that the risen Lord possesses and executes which is

William Loader, Boris Repschinski, Eric Wong (Eds.)

Matthew, Paul, and Others: Asian Perspectives on New Testament Themes

(C) 2019 innsbruck university press, ISBN 978-3-903187-66-5, DOI 10.15203/3187-66-5 
constantly active and available to the believer (Meyer, 1885; O'Brien, 1991). It is equally important to stress that the ultimate source of this all-encompassing and life-giving power is God the Father, with its knowledge arising from faith, and is the "transforming force that vitalizes Christian life and molds the suffering of the Christian to the pattern which is Christ" (Fitzmyer, 1970, p. 420). In light of Philippians 2:9-11 wherein God is the primary actor who exalted Christ above all else, this retracing of the source of the power of resurrection to him is indeed appropriate (Hansen, 2009).

The noun kouvovía is a common Pauline expression in his letters. It is commonly translated "fellowship," but the Greek term includes a wider range of meaning signifying a close relationship, such as association, communion, contribution, partnership, participation, and sharing (BDAG, 2000; LSJM,

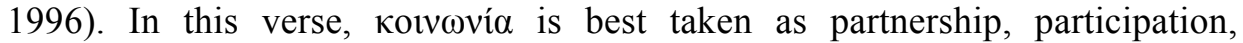
fellowship, or sharing (Hansen, 2009). The objective genitive $\pi \alpha \theta \eta \mu \alpha ́ \tau \omega \nu$ specifies the object of Paul's participation, i.e., he wants to share in the sufferings of Christ (Seesemann, 1933; Koperski, 1996). The plural "sufferings" do not refer to Christ's passion on the cross leading to his once-for-all sacrificial death for our redemption, which are usually expressed through words like cross, death, and blood in Pauline letters (O'Brien, 1991). Rather these sufferings refer to various kinds of adversities and afflictions that Christians experience in their union with Christ, both external and internal struggles (Hansen, 2009). Paul speaks of his being in chains for Christ and for the sake of the gospel, his struggles in the past and at present, and also sufferings of the Philippian believers $(1: 7,13,14,17,30)$. In another letter, he lists specific outward sufferings and inward struggles (2 Cor 11:12-29). Paul does not relish in the sufferings in and of themselves, but he delights in the deeper fellowship and communion with Christ through them. He has adequately expressed his perspective on sufferings when he exclaims that to suffer for Christ is a gift from God: "For he has graciously granted you the privilege not only of believing in Christ, but of suffering for him as well" (1:29 NRSV; emphasis added).

"It is impossible to know the power of his resurrection without participation in his sufferings." It is equally true that one cannot participate in his sufferings unless one experiences the power of the resurrection, because it is only by knowing the latter that one can have the encouragement and tenacity to endure the former (O'Brien, 1991; Hansen, 2009). "Without the power inherent in

William Loader, Boris Repschinski, Eric Wong (Eds.)

Matthew, Paul, and Others: Asian Perspectives on New Testament Themes

(C) 2019 innsbruck university press, ISBN 978-3-903187-66-5, DOI 10.15203/3187-66-5 
Christ's resurrection, present suffering (even for Christ's sake) is meaningless" (Fee, 1995, p. 330). This may well explain the reason why resurrection is mentioned first before suffering, which is an inversion of the usual sequence of events, but the conjoining of both words with a single article means that the reordering may not be consequential (Michael, 1927). It is fascinating that Paul combines power of the resurrection and fellowship of sufferings here, just as humiliation and exaltation are weaved together in the Christ-hymn. He wants to know Christ deeply and fully that he embraces both his victory and pain. This kind of knowledge is not superficial, but intimate, personal, and experiential (Fee, 1995; Hansen, 2009). Paul here expresses his intense desire to know Christ deeply and fully that it requires the response of his entire being, just as the surpassing knowledge of Christ Jesus in verse 8 brings about a radical change in his perspective and attitude (O'Brien, 1991).

What does Paul mean that he wants to be conformed to Christ's death

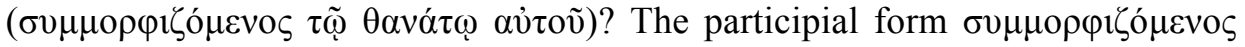
only occurs in this verse in the NT, but its cognate noun $\mu о \rho \varphi \eta$ appears twice in the carmen Christi $(2: 6,7)$ which shows "how Paul is intentionally identifying his experience with the narrative of Christ" (Hansen, 2009, p. 246, emphasis added). Paul could have chosen another word like $\sigma v \sigma \chi \eta \mu \alpha \tau i \zeta o \mu \alpha$ (cf. Rom 12:2), but his deliberate use of $\sigma v \mu \mu о \rho \varphi$ í $\mu_{\alpha}$ implies his intention to look back to the Christ hymn. Bockmuehl comments, "There is a reasonable likelihood that the apostle may be deliberately raising the issue of the 'form' of Christ's death to indicate that his own former motivation of pride has given way to one of Christ-like humility" (Bockmuehl, 1997, p. 216). The word comes from the verb $\sigma v \mu \mu о \rho \varphi$ í $\omega$ which means to be like something by taking the same form (BDAG, 2000). The present tense signifies that it is a continuous, ongoing process that precludes the possibility of reading it as a baptismal allusion (Koperski, 1996). The medio-passive form $\sigma u \mu \mu о \rho \varphi$ ¿ó $\mu \varepsilon v o \varsigma$ combined with a dative is best taken in its passive sense, i.e., Paul is being conformed to Christ's death (BDAG, 2000; O'Brien, 1991; Hansen, 2009). The cognate adjective $\sigma 0 ́ \mu \mu \rho \rho \varphi$ ov in verse 21 depicts Christ as the "who will transform the body of our humble state into conformity with the body of His glory" (NASB). The same adjective is used in Romans 8:29 and speaks of God as the one who conforms those whom he has chosen to be conformed to the image of his Son: "For those whom he foreknew he also predestined to be conformed to the image of his Son, in order that he might be the first-born among many brethren"

William Loader, Boris Repschinski, Eric Wong (Eds.)

Matthew, Paul, and Others: Asian Perspectives on New Testament Themes

(C) 2019 innsbruck university press, ISBN 978-3-903187-66-5, DOI 10.15203/3187-66-5 
(RSV). Here we see a clear picture of divine empowerment and human participation working hand in hand to bring about our conformity to Christ (Koperski, 1996). Paul actively seeks to gain Christ and to know him (active forms $\kappa \varepsilon \rho \delta \eta ் \sigma \omega$ and $\gamma \nu \tilde{\omega} v \alpha$ l), yet he also willingly submits to God and let him do his work in his life, so that he may be found in Christ and be continually conformed to him (passive forms $\varepsilon \dot{v} \rho \varepsilon \theta \tilde{\omega}$ and $\sigma v \mu \mu о \rho \varphi \imath \zeta o ́ \mu \varepsilon v o \varsigma)$.

This participial phrase may be construed as an adverbial participle of means

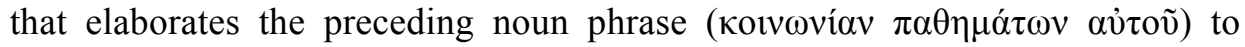
explain that the way to know the fellowship of Christ's sufferings is "by becoming like him in his death" (NRSV). It may also function as a result participle, i.e., sharing in Christ's sufferings brings about conformation to his death (Hansen, 2009). It is best to take the participial phrase as modifying the entire verse: "It is not in the fellowship of Christ's sufferings as such that Paul is conformed to Christ's death; rather, it is by participating in those sufferings . . . and as strengthened to do so in the power of his resurrection that he is continually being conformed to Christ's death" (O'Brien, 1991, p. 407, emphasis original). Byrnes's proposal to consider the phrase a result participle that summarizes the outcome of the whole process is also convincing. Byrnes (2003) elucidates as follows:

We already have a iv $\alpha$ clause describing the purpose of Paul's reevaluation and renunciation of all things, and an infinitive clause explanatory of the consequences, namely, the knowledge of Christ in his resurrection and sufferings. The participial phrase seems to be added to clarify the result of the whole process. In other words, Paul, by the evaluation of all things as loss and the subsequent forfeiture of all things for the sake of knowing Christ both in the power of his resurrection and in participation in his sufferings, is being conformed to the pattern of Christ's own death on the cross (p. 228).

It is also important to note that the participle $\sigma v \mu \mu \rho \rho \varphi \imath \zeta o$ $\mu \varepsilon v o \varsigma$ is dependent on the articular infinitive $\tau$ ov $\gamma \nu \tilde{\omega} v \alpha \mathrm{l}$ and depicts how knowledge is gained (Bockmuehl, 1997). Hence, Paul is also continually conformed to Christ, by knowing his mindset and perspective on humiliation and exaltation. It is certainly appropriate to specify that conformation should not be limited to Christ's death only, but it extends to every sphere of the Christian life, which is primarily characterized by Christ's death (Fee, 1995).

I submit that it is best to interpret "being conformed to his death" as an ongoing inward transformation akin to Christ's death. I have come to this

William Loader, Boris Repschinski, Eric Wong (Eds.)

Matthew, Paul, and Others: Asian Perspectives on New Testament Themes

(C) 2019 innsbruck university press, ISBN 978-3-903187-66-5, DOI 10.15203/3187-66-5 
conclusion based on the following points of convergence: (1) This participial phrase modifies not just the immediate preceding noun phrase, but relates to the entire verse, i.e., conformity to Christ is not only in sharing in his sufferings, but also in experiencing the power of the resurrection and in coming to know Christ more fully and deeply (O'Brien, 1991); (2) Paul's focus in this passage is not so much on the physical events of Christ's sufferings, death, and resurrection, but more on his desire to know Christ more deeply by experiencing the power and fellowship of sharing in these events (O'Brien, 1991); (3) The present tense of the participle shows this is a continual process of being conformed to Christ in every area of the believer's life, and not just towards the end of his life when he is facing death (Hansen, 2009); (4) The passive voice of the participle may be construed as a divine passive whereby God is at work to bring about spiritual transformation and daily renewal to conform his people to his Son (O'Brien, 1991); (5) The nature of the conformation does not necessarily have to be exactly like that of Christ's death, but rather akin to his death in terms of his perspective on humiliation and exaltation as vividly portrayed in the carmen Christi; and (6) Paul's recounting of his personal experience which is in close parallel to the narrative of Christ in the hymn is not intended as an exclusive apostolic enterprise of martyrdom, but an encouragement for all believers to participate and experience (O’Brien, 1991).

\section{Interpretation of the Christ-Hymn}

In this section I will first revisit the hymn and take a closer look at the mind of Christ, his humiliation and exaltation. I will then offer an alternative reading of the carmen Christi by expounding on Christocentric ethics and highlighting the theme of conformity to Christ.

\section{Revisiting the Carmen Christi}

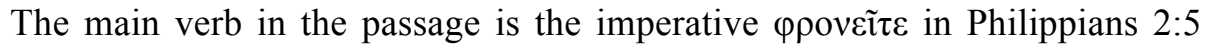
(the next verb is only encountered again in 2:9) and reveals the mind of Christ. How this imperative is understood is crucial to the interpretation of the verse

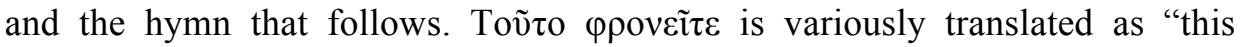
think" or "have this mindset." I agree with Fee that the force of the imperative verb should be clearly carried out by focusing on the action, instead of the noun

William Loader, Boris Repschinski, Eric Wong (Eds.)

Matthew, Paul, and Others: Asian Perspectives on New Testament Themes

(C) 2019 innsbruck university press, ISBN 978-3-903187-66-5, DOI 10.15203/3187-66-5 
that is implied in the verb (Fee, 1995). He cautions that to emphasize on the implied noun by translating the first two words as "have this mindset" or "have this frame of mind" is misleading because this hypothetical noun will be assumed as the antecedent of the relative pronoun on that comes after (Fee, 1995). Grammatically $\tau$ oṽ $\tau$ is the object of the main verb $\varphi \rho о v \varepsilon \tilde{\tau} \varepsilon \varepsilon$ and the antecedent of the relative pronoun ö (Fee, 1995).

The first part of the verse ends with $\dot{\varepsilon} v$ v $\mu \mathrm{i} v$ which could be translated as "in you" (individually) or "among yourselves" (relationally). If the former, then the plural $\dot{v} \mu \mathrm{i} v$ refers to individual members in the congregation in a distributive sense, i.e., within you or in each of you (Hellerman, 2015). If the latter, then the plural $\dot{v} \mu \mathrm{i} v$ refers to a collective sense, i.e., among you in relation to each other (Silva, 2005; O'Brien, 1991; Hellerman, 2015). As mentioned above the demonstrative pronoun $\tau$ oṽ $\tau$ refers back to the attitudes that Paul is exhorting the Philippian believers to think of in 2:1-4, then the relational emphasis is more appropriate when we consider Paul's emphasis on how they relate to one other (Hellerman, 2015). The prepositional phrase is also more commonly used in Pauline paraenesis to articulate what he wants the believing community to put into practice (Fee, 1995). Needless to say, the corporate appeal implies an individual response (Fee, 1995). As Silva points out, it is more common to use $\dot{\varepsilon} v \dot{\varepsilon} \alpha v \tau o \tilde{\iota} \zeta$, instead of $\dot{\varepsilon} v \dot{v} \mu \mathrm{i} v$, when describing someone who is thinking to or within himself (Silva, 2005).

The relative clause that begins with ô kai has the demonstrative pronoun $\tau$ ๙ovंo as its antecedent, which in turn is referring to the attitudes of humility and being like-minded in vv. 2-4 (Fee, 1995). Hence, it makes more sense to take

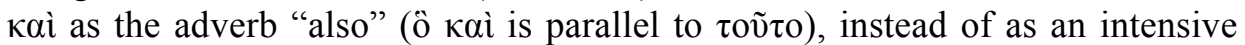
"even" or "indeed" (O'Brien, 1991).

Now we come to the verb that needs to be supplied in the second part of the verse. According to traditional interpretation, which is also called the ethical interpretation, the verb $\tilde{\eta} v$ is usually supplied in the relative clause in combination with the "within you" (individual sense) in the first part of the verse (Silva, 2005). This view interprets Christ as the ethical pattern that Christians should imitate, with the prepositional phrase $\dot{\varepsilon} v$ X $\rho\llcorner\sigma \tau \tilde{\omega}$ 'I $\eta \sigma o v$ understood in an individual sense, i.e., Christ's inward attitude of humility and self-sacrifice (Silva, 2005; O'Brien, 1991). Thus the verse is translated as: "Think this within you which also was in Christ Jesus" (Morgan, 1998, p. 56, emphasis original).

William Loader, Boris Repschinski, Eric Wong (Eds.)

Matthew, Paul, and Others: Asian Perspectives on New Testament Themes

(C) 2019 innsbruck university press, ISBN 978-3-903187-66-5, DOI 10.15203/3187-66-5 
The rival interpretation (kerygmatic view) advocated by Käsemann and

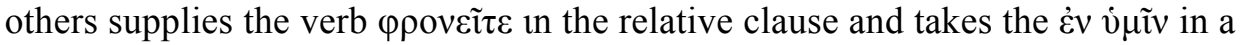
relational sense (Silva, 2005). Käsemann understands the verse as an introduction to the hymn and that "the Philippians are admonished to conduct themselves toward one another as is fitting within the realm of Christ"

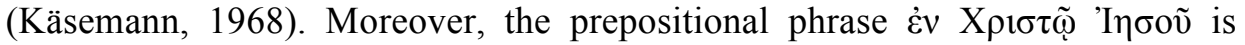
taken as the typical formula of $\dot{\varepsilon} v$ X $\rho \sigma \tau \tilde{\varrho}$ which is common in Paul's letters, referring to our union with Christ (Silva, 2005). Thus the verse is translated as: Think this among you that which you also think in your union with Christ (Moule, 1970). Hansen explains that this rendering underscores the parallelism

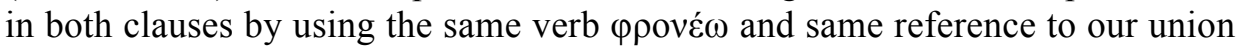
with Christ as a corporate body (Hansen, 2009). Proponents of this interpretation believe that the hymn is intended as a kerygmatic proclamation of the Christ event and not as ethical example to be imitated (Hansen, 2009). "By placing the proclamation of Christ in the hymn after moral exhortation," he elucidates, "Paul is pointing to the power of transformation. Christian behavior is motivated and empowered by salvation in Christ, not by the example of Christ" (Käsemann, 1968).

A slight variation of this is C. F. Moule's expansion of the verse: $\tau$ oṽ $\tau$ o

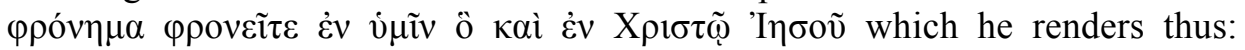
"Adopt towards one another, in your mutual relations, the same attitude which was found in Christ Jesus" (Moule, 1970, p. 265). It is intended as a corrective to the inferior reading $\varphi \rho o v \varepsilon i ́ \sigma \theta \omega$ (present passive imperative) adopted by the Authorized Version and rendered as "Let this mind be in you" (KJV). Moule takes $\dot{\varepsilon} v \dot{v} \mu \tilde{i} v$ as a reference to interpersonal relationships among believers in contrast to the Authorized Version which takes the prepositional phrase to mean "within each of you" or "in your hearts" (Moule, 1970, p. 265). However, he adopts the second part of the said version "which was also in Christ Jesus" because he considers it a false assumption that $\dot{\varepsilon} v$ X refer to Pauline formula of incorporation in Christ (Moule, 1970). The other false assumption Moule is unmasking is that unless both prepositional phrases

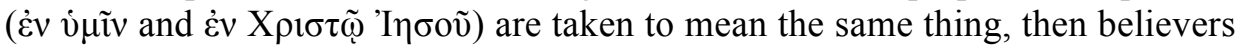
could be suspected of maintaining two separate attitudes - one regarding their relationship with each other and another pertaining to their being union with Christ (Moule, 1970). He perceives the two relationships as "one and inseparable" and that "the contrast is not between two spheres of existence but

William Loader, Boris Repschinski, Eric Wong (Eds.)

Matthew, Paul, and Others: Asian Perspectives on New Testament Themes

(C) 2019 innsbruck university press, ISBN 978-3-903187-66-5, DOI 10.15203/3187-66-5 
between an already given condition, on the one hand, and the implementing of it, on the other" (Moule, 1970). He cites 4:2 as a close parallel to prove his point-Paul is urging Euodia and Syntyche to live in harmony with each other "as being in the Lord" ( harmonious in the Lord" (Moule, 1970, p. 266). Although Paul's "in Christ" expressions are well-known in his other letters, it does not make sense here contextually. If $2: 5$ is a transitional to the following hymn, as previously noted, then the supposed reference to our union with Christ should correspond to the relative pronoun in the following verse. But the relative pronoun ôs in 2:6 refers to Christ and describes his mindset of humility and self-sacrifice.

Christ's mindset, introduced in v. 5, is further explained in the next three verses as the mindset of Christ as God (v. 6) and as a man (vv. 7-8) (Fee, 1995). These verses spell out the humiliation of Christ in two main clauses, joined by $\kappa \alpha 1$, with a similar threefold structure: (1) each clause is introduced by a participial phrase that describes how Christ existed as God ( $\dot{\varepsilon} \vee \mu \circ \rho \varphi \tilde{n} \theta \varepsilon$ v

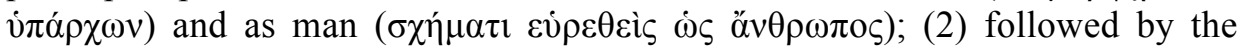

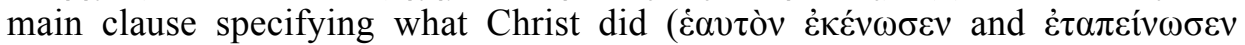
$\dot{\varepsilon} \alpha v \tau$ òv); and (3) followed by a modal participle that modifies the key verb and

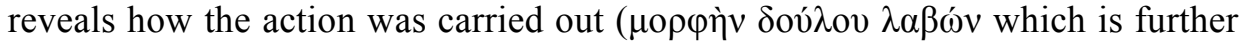

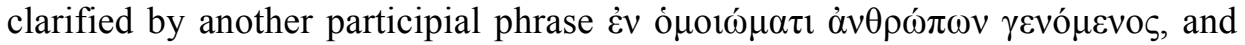

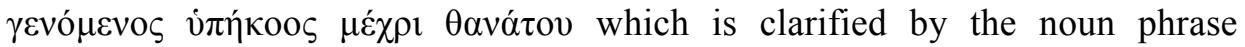

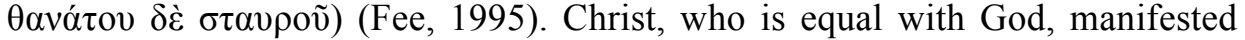
his humiliation by becoming a man, but more than that, he also took the form of a servant and experienced the most humiliating death and endured the most excruciating pain. By employing a remarkable "not ... but" contrast (cf. vv. 2-4 for similar contrast), Paul presents two ways of thinking or mindset, one that is selfish, and the alternative is selfless (Fee, 1995).

The second part of the hymn is introduced by $\delta$ iò $\kappa \alpha \grave{i}$ and reveals significant shifts in themes and emphasis. Whereas the first part focuses on Christ, God the Father is the key player and subject of the main verbs in the second part (Brown, 1998; Fee, 1995; Hansen, 2009; O'Brien, 1991). Whereas humiliation is the primary motif in the first section, exaltation is the key theme in the latter section. Despite the distinction between the two parts, the emphatic inferential

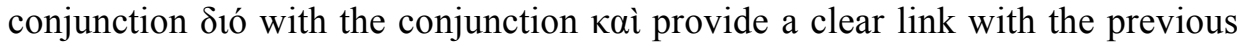
verses, mark an inference based on what was stated in those verses, and signal

William Loader, Boris Repschinski, Eric Wong (Eds.)

Matthew, Paul, and Others: Asian Perspectives on New Testament Themes

(C) 2019 innsbruck university press, ISBN 978-3-903187-66-5, DOI 10.15203/3187-66-5 
the transition from the theme of Christ's humiliation to an exaltation motif (Brown, 1998; O’Brien, 1991).

\section{Christocentric Ethics}

I believe that the best way to interpret the passage is to integrate both kerygmatic and ethical interpretation. It is not helpful to pit one against the other and miss a key point when one argument is emphasized at the expense of the other. Unfortunately, a great part of the ongoing debate is beset by false dichotomies and inundated with biases. We should be careful not to make a "superficial antithesis between Heilsgeschichte and ethics" (Strimple, 1979, p. 255). Hooker (1975) exclaims, "It is only the dogma that the Jesus of History and the Christ of faith belong in separate compartments that leads to the belief that the appeal to Christian character appropriate to those who are in Christ is not linked to the pattern as seen in Jesus himself" (p. 154). Paul's theology always springs forth in ethical implications, and his ethical injunctions are always grounded in firm theology. Hawthorne and Martin (2004) underscore this important point:

Hence, although this hymn (1) is unquestionably a Christological gem unparalleled in the NT, (2) may be considered soteriological, or better, kerygmatic, in character (yet with parenetic enforcement brought out in 2:12 as a call to obedience; there is no dichotomy between the two, . . ., and (3) may have been originally composed for christological or soteriological reasons, Paul's motive in using it here is not theological but ethical. Yet this disjunction may be granted to be chimerical since Paul's ethics are always theological ethics; i.e., the call is to act because God in Christ has acted in the first place. ... Paul's objective is not to give instruction in doctrine but to reinforce instruction (parenesis) in Christian living. And he does this by appealing to the event of Christ (p. 106, emphasis original).

A more comprehensive understanding of the passage will emerge if we base our theological understanding on sound exegesis and avoid, as much as possible, any preconceived way of defining the hymn. For lack of a better term, I will use "Christocentric ethics" to refer to Pauline ethics that is firmly grounded on a strong Christology. This does not mean that ethics is more central nor less important than Christology. I could have used "ethical

William Loader, Boris Repschinski, Eric Wong (Eds.)

Matthew, Paul, and Others: Asian Perspectives on New Testament Themes

(C) 2019 innsbruck university press, ISBN 978-3-903187-66-5, DOI 10.15203/3187-66-5 
Christology" interchangeably but the second label might create unnecessary confusion.

In summary, Christocentric ethics is seeking to strike a balance between theology and ethics. The key to solving the false dichotomy is to focus on Christ as the unifying factor of both theology and ethics.

\section{Conformity to Christ}

It is more helpful to speak of conformity to Christ, instead of issuing a call for an imitation of Christ's example (O'Brien, 1991; Gorman, 2009). For Paul Christian ethics is far more than mere imitation of Christ's example, it is rather a conformity to the true essence of life in Christ (Hooker, 1975). Seifrid (2000) captures this overarching theme of the letter succinctly: "Paul's purpose throughout is to set forth believing life as conformation to Christ in both humiliation and exaltation" (pp. 88-89, emphasis added). We are not called to imitate specific actions in the hymn, but rather to cultivate the mindset of Christ which will then affect our choices, decisions, attitudes, behavior, and relationships (Fee, 1995).

Christ's way of thinking is clearly demonstrated by his humility and selfless service in the historical events of incarnation and crucifixion in 2:6-8 (Keener, 2016). Paul appeals to the believers to adopt this mindset to rally them to aim

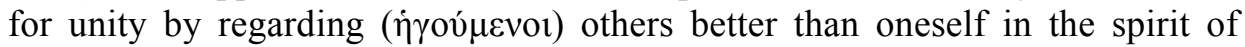
humility ( $\tau \alpha \pi \varepsilon$ vo $\rho \rho \sigma u ́ v \eta)$ in the same way that Christ did not regard

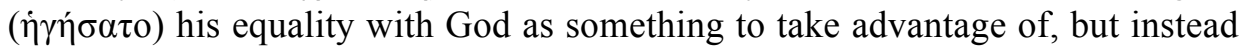
he humbled himself ( $\dot{\varepsilon} \tau \alpha \pi \varepsilon i ́ v \omega \sigma \varepsilon v)$ (Keener, 2016). We also need to emphasize that Christ has done so willingly - he emptied and humbled himself $(2: 7,8)$. The reflexive pronoun $\dot{\varepsilon} \alpha v \tau o ̀ v$ signifies the voluntary nature and deliberateness of the decision made, not out of compulsion, but motivated by love and selflessness (Martin, 1997). This needs to be stressed because when we simply imitate Christ or follow his example, we may do so in order to fulfill certain expectations or obligations. But when we have the mind of Christ, we actively engage in looking at things and evaluating them through his perspective.

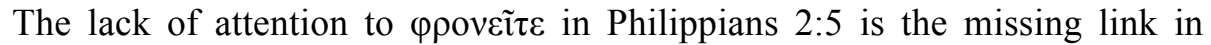
understanding and interpreting the hymn which led scholars to postulate the false dichotomy that it is either kerygmatic or ethical interpretation. In contrast conformatio Christi is far broader than the narrow and limited concept of

William Loader, Boris Repschinski, Eric Wong (Eds.)

Matthew, Paul, and Others: Asian Perspectives on New Testament Themes

(C) 2019 innsbruck university press, ISBN 978-3-903187-66-5, DOI 10.15203/3187-66-5 
imitatio Christi and more comprehensive than virtue ethics. I argue that the former is both active and passive, which is a paradox in itself. It is active in the sense that Paul calls for the believers to actively seek to think (present active imperative $\varphi \rho \circ v \varepsilon i \tau \varepsilon)$ in conformity to mind of Christ. We also see Christ willingly and voluntarily lay down his life and pour himself out. Kierkegaard is on target when he exclaims that there is only one Christ and no one can do exactly as he did. His work of redemption and salvation is unique and extraordinary which only he can accomplish at his own initiative. We cannot imitate his incarnation, crucifixion, or exaltation, but we can cultivate his mindset of readiness and willingness to suffer humiliation in service to others. It is passive in the sense that Paul did not actively seek out suffering for himself, unlike the martyrs, nor did he exhort the Philippians to do so. Unlike Christ humiliation and suffering essentially come to us, not what we create or avidly pursue, which spells out our essential distinction from him as Kierkegaard noted. Jesus' obedience and exaltation are unique in nature that the obedience in Philippians 2:6-8 cannot be simply replicated (Hurtado, 1984). Therefore, it is proper to say that the passage is not urging strict imitatio Christi, but rather conformatio Christi, whereby believers not just imitate Christ's action, but conform to his pattern of thinking, acting, and serving (Dahl, 1976).

\section{Conclusion}

Conformity to Christ is a recurring process of renewal and reshaping that affects even the way we think and make decisions. This brings us to an important point in my thesis. Paul's conformity to Christ is reflected in how he regards his assets and liabilities. He did not say that all things are garbage in and of themselves, but that he counts them as such (Witherington, 2011). The verb $\dot{\gamma} \gamma \varepsilon$ 'o $\alpha$ involves "considered reflection," careful process of evaluation, and weighing of options, and Paul narrates his own story "in a way parallel to how he has described the Son's heavenly decision-making about all the good things he could have taken advantage of" (Witherington, 202). Not only is the same verb ( $\dot{\eta} \gamma \dot{\varepsilon} \circ \mu \alpha \imath)$ used in both the stories of Christ and Paul, but it is also closely linked to the $\varphi \rho \circ v \varepsilon i \tau \varepsilon$ in Philippians 2:5. It is because of this transformation in Paul's thinking and decision-making, so he is able to rejoice and encourage others to rejoice while he is languishing in jail. His Christ-centered and gospelfocused perspective transcends the dire circumstances of his imprisonment so he

William Loader, Boris Repschinski, Eric Wong (Eds.)

Matthew, Paul, and Others: Asian Perspectives on New Testament Themes

(C) 2019 innsbruck university press, ISBN 978-3-903187-66-5, DOI 10.15203/3187-66-5 
can confidently declare that "what has happened to me has actually served to advance the gospel" (1:12 NIV). This transformed perspective also fuels Paul's desire to know Christ and enables him to embrace both the power of the resurrection and the fellowship of sufferings, which expresses Paul's aspiration "to know the whole Christ" (Byrnes, 2003, p. 243). "Paul wants to know Christ in every aspect of his life, death, and resurrection. He desires knowledge by experience and participation. He desires a relationship that is total and allencompassing" (Byrnes, 2003, p. 243). Fee (1995) summarizes Paul's transformation succinctly:

... Christ's resurrection guaranteed his own, that he could throw himself into the present with a kind of holy abandon, full of rejoicing and thanksgiving; and that not because he enjoyed suffering, but because Christ's resurrection had given him a unique perspective on present suffering ... a as well as an empowering presence whereby the suffering was transformed into intimate fellowship with Christ himself (p. 331, emphasis added).

God is indeed at work and continues to work. He is active and alive in our lives, and we are his workmanship. This element of total dependence on God to do his work in us is the missing piece in the concept of imitatio which focuses more on our human efforts to imitate Christ and be like him. This is in a sense the shallow ethical idealism against which Käsemann is protesting wherein God and the drama of salvation are missing from the picture. But Paul has a robust soteriology that incorporates both the kerygmatic and ethical aspects of justification, sanctification, and glorification - God's active work of redemption ("righteousness from God through faith in Christ" 3:9) and regeneration ("We are God's handiwork, created us in Christ Jesus to do good works" Eph 2:10 NIV) that lays the foundation which enables us to will and to work for his good pleasure $(2: 12)$, to share in his sufferings $(3: 10$; Rom $8: 17)$ as we are sustained by the power of the resurrection (3:10), so we may share in his glory (Rom $8: 17)$ and be conformed to his glorious body $(3: 21)$. Our ethical response, then, is grounded on dogmatic truths.

William Loader, Boris Repschinski, Eric Wong (Eds.)

Matthew, Paul, and Others: Asian Perspectives on New Testament Themes

(C) 2019 innsbruck university press, ISBN 978-3-903187-66-5, DOI 10.15203/3187-66-5 


\section{References}

Balz, H., \& Schneider, G. (Eds). (1993). Exegetical dictionary of the New Testament. Vol. 3. Grand Rapids, MI: Eerdmans.

Bauer, W., Danker, F. W., Arndt, W. F., \& Gingrich, F. W. (2000). A Greek-English lexicon of the New Testament and other early Christian literature (3rd ed.). Chicago, IL: University of Chicago Press.

Beekes, R. (2010). Etymological dictionary of Greek. In Leiden Indo-European etymological dictionary series. Leiden, Netherlands: Brill.

Bertram, G. (1974). In G. Friedrich and G. W. Bromiley (Eds.), The Theological dictionary of the New Testament (Vol. 9, pp. 220-35). Grand Rapids: Eerdmans.

Bockmuehl, M. (1997). The Epistle to the Philippians. (4th ed.). In Black's New Testament Commentaries. London: A \& C Black.

Brown, C. (1998). Ernst Lohmeyer's Kyrios Jesus. In R. P. Martin \& Brian J. Dodd, Where Christology began: Essays on Philippians 2 (pp. 6-42). Louisville: Westminster John Knox Press.

Byrnes, M. (2003). Conformation to the death of Christ and the hope of resurrection: An exegetico-theological study of 2 Corinthians 4,7-15 and Philippians 3,7-11. Rome: Gregorian University Press.

Dahl, N. A. (1976). Jesus in the Memory of the Early Church. Minneapolis: Augsburg.

DeSilva, D. A. (1994). No Confidence in the Flesh: The Meaning and Function of Philippians 3:2-21. Trinity Journal, 15 (1), 27-54.

Fee, G. D. (1995). Paul's Letter to the Philippians. In the new international commentary on the New Testament. Grand Rapids, MI: Eerdmans.

Fee, G. D. (1999). Philippians. In G. R. Osborne, The IVP New Testament commentary aeries. Downers Grove, IL: Inter-Varsity Press.

Fitzmyer, J. A. (1970). To know him and the power of his resurrection (Phil 3.10). In A. Descamps \& A. de Halleux (Eds.), Mélanges bibliques en hommage au R. P. Bêda Rigaux (pp. 411-25). Gembloux, Belgium: Duculot.

Fowl, S. E. (2005). Philippians. In The two horizons New Testament commentary. Grand Rapids, MI: Eerdmans.

Garland, D. E. (1985). The Composition and Unity of Philippians: Some Neglected Factors. Novum Testamentum 27 (2), 141-73.

Godet, F. L (1977). Commentary on Romans. Grand Rapids, MI: Kregel.

Gorman, M. J. (2009). Inhabiting the Cruciform God: Kenosis, Justification, and Theosis in Paul's Narrative Soteriology. Grand Rapids, MI: Eerdmans.

Hansen, G. W. (2009). The Letter to the Philippians. In D. A. Carson, The pillar New Testament commentary. Grand Rapids: Eerdmans.

William Loader, Boris Repschinski, Eric Wong (Eds.)

Matthew, Paul, and Others: Asian Perspectives on New Testament Themes

(C) 2019 innsbruck university press, ISBN 978-3-903187-66-5, DOI 10.15203/3187-66-5 
Hawthorne, G. F. (1983). Philippians. In Word Biblical Commentary (Vol. 43). Waco, TX: Word Books.

Hawthorne, G. F., \& Martin, R. P. (2004). Philippians (Rev. ed.) In Word Biblical Commentary (Vol. 43). Nashville, TN: Thomas Nelson.

Hellerman, J. H. (2015). Philippians. In Exegetical guide to the Greek New Testament. Nashville, TN: B\&H Academic.

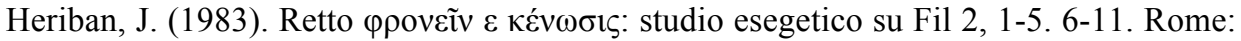
Liberia Ateneo Salesiano.

Heriban, J. (1994). [Review of the book The Epistle to the Philippians: A Commentary on the Greek Text, by Peter T. O'Brien]. Biblica 75 (1), 121-25.

Hooker, M. D. (1975). Philippians 2:6-11. In E. E. Ellis \& E. Grässer (Eds.), Jesus und Paulus: Festschrift für werner Georg Kümmel Zum 70. Geburtstag (pp. 15164). Tübingen: Mohr Siebeck.

Hurtado, Larry W. (1984). Jesus as Lordly Example in Philippians 2:5-11. In P. Richardson \& J. C. Hurd (Eds.), From Jesus to Paul: Studies in Honour of Francis Wright Beare (pp. 113-26). Ontario: Wilfrid Laurier University Press.

Käsemann, E. (1968). A critical analysis of Philippians 2:5-11 (R. W. Funk, Ed. \& A. F. Carse, Trans). Journal for Theology and the Church 5, 45-88.

Käsemann, E. (1980). Commentary on Romans (G. W. Bromiley, Ed. \& Trans.). Grand Rapids, MI: Eerdmans.

Keener, C. S. (2016). The mind of the spirit: Paul's approach to transformed thinking. Grand Rapids, MI: Baker Academic.

Koperski, V. (1996). The knowledge of Christ Jesus my Lord: The high Christology of Philippians 3:7-11. Kampen, Netherlands: Kok Pharos.

Kurz, W. S. (1985). Kenotic Imitation of Paul and of Christ in Philippians 2 and 3. In F. F. Segovia (Ed.), Discipleship in the New Testament. Philadelphia, PA: Fortress.

Louw, J. E. \& E. A. Nida (1989). Greek-English lexicon of the New Testament based on semantic domains (2nd ed.) New York, NY: United Bible Societies.

Liddell, H. G., Scott, R., Jones, H. S., \& McKenzie, R. (1996). A Greek-English lexicon (9th ed. with revised supplement). Oxford: Clarendon Press.

Martin, R. P. (1997). A hymn of Christ: Philippians 2:5-11 in recent interpretation and in the setting of early Christian worship. Downers Grove, IL: InterVarsity.

Meyer, H. A. W. (1885). Critical and exegetical hand-book to the epistles to the Philippians and Colossians, and to Philemon. In J. C. Moore (Trans.), Meyer's commentary on the New Testament. New York, NY: Funk \& Wagnalls.

Montanari, F. (2015). The Brill Dictionary of Ancient Greek (M. Goh \& C. Schroeder, Eds.). Leiden, Netherlands: Brill.

William Loader, Boris Repschinski, Eric Wong (Eds.)

Matthew, Paul, and Others: Asian Perspectives on New Testament Themes

(C) 2019 innsbruck university press, ISBN 978-3-903187-66-5, DOI 10.15203/3187-66-5 
Morgan, R. (1998). Incarnation, Myth, and Theology: Ernst Käsemann's Interpretation of Philippians 2:5-11. In R. P. Martin \& B. J. Dodd, Where Christology Began: Essays on Philippians 2 (pp. 43-73). Louisville, KY: Westminster John Knox.

Moule, C. F. D. (1970). Further Reflexions on Philippians 2:5-11. In W. W. Gasque and R. P. Martin (Eds.), Apostolic History and the Gospel: Biblical and Historical Essays Presented to F.F. Bruce on His 60th Birthday (pp. 264-76). Grand Rapids, MI: Eerdmans.

O'Brien, P. T. (1991). The epistle to the Philippians: A commentary on the Greek text. In The new international Greek testament commentary. Grand Rapids, MI: Eerdmans.

Pollard, T. E. (1966). Integrity of Philippians. New Testament Studies 13 (1), 57-66.

Reed, J. T. (1997). A Discourse Analysis of Philippians: Method and Rhetoric in the Debate over Literary Integrity. In Journal for the Study of the New Testament Supplement Series 136. Sheffield, UK: Sheffield Academic.

Seesemann, H. (1993). Der begriff KOINONIA im Neuen Testament. In Zeitschrift für die neutestamentliche Wissenschaft und die Kunde der älteren Kirche 14. Giessen, Germany: Alfred Töpelmann.

Seifrid, M. (2000). Christ, our righteousness: Paul's theology of justification. In New studies in biblical theology. Downers Grove, IL: InterVarsity.

Silva, M. (2005). Philippians (2nd ed.). In Baker exegetical commentary on the New Testament. Grand Rapids: Baker Academic.

Silva, M. (Ed.). (2014). New international dictionary of New Testament theology and exegesis. (Vol. 4). Grand Rapids, MI: Zondervan.

Strimple, R. (1979). Philippians 2:5-11 in recent studies: some exegetical conclusions. Westminster Theological Journal, 41 (2), 247-268.

Tannehill, R. C. (1967). Dying and rising with Christ: A study in Pauline theology. In Zeitschrift für die neutestamentliche Wissenschaft und die Kunde der älteren Kirche 32. Berlin, Germany: Verlag Alfred Töpelmann.

Wallace, D. B. (1996). Greek grammar beyond the basics: An exegetical syntax of the New Testament. Grand Rapids, MI: Zondervan.

Witherington III, B. (2011). Paul's letter to the Philippians: A socio-rhetorical commentary. Grand Rapids, MI: Eerdmans. 
